Journal of Management and Business Aplication

\title{
THE ROLE OF ORGANIZATIONAL CITIZENSHIP BEHAVIOR IN AN EFFORT TO IMPROVE LECTURER PERFORMANCE AT PRIVATE UNIVERSITIES IN JEMBER
}

\author{
Tamriatin Hidayah ${ }^{1}$ \\ Hary Sulaksono ${ }^{2}$
}

Higher Education of Economic Mandala

Email : titin@stie-mandala.ac.id

\begin{abstract}
This study aims to see the influence of the variable leadership style, organizational culture, compensation on performance through the variable Organizational Citizenzhip Behavior as an Intervening variable. The research was conducted at private universities in Jember. Methods of data collection through distribution of questionnaires. The data analysis method used was SEM. The results obtained from this study are that there is a direct influence of leadership style, organizational culture, and compensation on lecturer performance. Indirect influence through the intervening variable Organizational Citizenship behavior. The implications that can be formulated in relation to the results of this study are that higher education leaders should always apply a leadership style that is able to encourage the improvement of lecturer performance.
\end{abstract}

Keywords: Leadership Style, Organizational Culture, Compensation, Performance, Organizational Citizenship Behavior

\section{INTRODUCTION}

Globalization provides opportunities as well as challenges for Indonesia to further enhance competitiveness. The consequences of globalization have an impact on various fields. Higher education in Indonesia faces challenges as well as opportunities to prepare human resources to be able to adapt to the demands of the times in the era of the industrial revolution 4.0 (RI 4.0).

The role of Human Resources in an organization is very important. Every organization, whatever it is, should think about performance management issues.
Employee performance or individual performance in an organization will affect group performance which in turn will affect organizational performance. Performance management is the overall activity carried out to improve organizational performance.

Performance is a description of the level of achievement of the implementation of an activity / program / policy in realizing the goals, objectives, vision and mission of the organization.

The performance of an University is determined by the performance of its Human Resources (HR), especially the academic community, namely Lecturers and Students. HR is a very important part 
in improving and developing an organization. An institution or organization that has human resources with good performance will relatively find it easier to achieve organizational goals.

Richard L. Daft (2003) states that OCB is a work behavior that exceeds job requirements and plays a role in organizational success. Organizations will be successful if employees do not only do their main tasks, but also want to do extra tasks such as cooperating, helping, giving advice, participating actively, providing extra services to customers, and willing to use their time effectively.

The increase in employee OCB can be identified by various factors that influence it. According to the opinion of Organ, et al (20060 the increase in OCB is influenced by two factors: internal and external factors. Internal factors such as job satisfaction, commitment and personality. External factors such as Leadership Style, Organizational Culture, Compensation.

Leadership Style has a contribution to employee OCB, this is in accordance with research from (Zang et al 2010), (Pratikto et al. 2015), (Malik, et al 2016) In addition to leadership style, Organizational Culture is another variable that affects OCB. (Jerald Greenberg and Robert A. Baron 2003). Organizational culture is a cognitive framework consisting of attitudes, values, behavioral norms and expectations that are accepted by organizational members. The influence of Organizational Culture on $\mathrm{OCB}$ is in accordance with research from (Kwantee, 2008), (Ahmadi ,2010). The results are slightly different from research from Arumi et al. (2019) who concluded that organizational culture affects Organizational Citizenship Behavior through Organizational Commitment. A good organizational culture can be reflected in the behavior of employees who initiate new ideas, are sensitive to customer / student needs and have the freedom to communicate with each other between employees, teams and leaders.
In order to encourage the achievement of organizational goals, employee performance that shows OCB behavior is needed, however, every employee must have an interest and expectation in the form of a reward for every work done. It is necessary to have alignment between the goals of the organization and the interests of the employees, in this case the organization must pay more attention to employees in the form of compensation. because compensation is part of a reciprocal relationship between the organization and the work of employees.

Compensation according to (Hasibuan, 2007) is all income in the form of money or goods, directly or indirectly received by employees as compensation for services provided to the company.

Compensation is another important variable that can create OCB behavior in an organizational environment. Findings from (Muayanah et al 2015), (AA Ngurah Bagus Danendra, et al. 2016), (SindhiSaraayu Prasetyo and Ahyar Yuniawan 2016), (Nabawi et al 2018) Compensation affects OCB, research from (Yuni Ambarwati ,2013) gave different results that compensation had no positive and insignificant effect on OCB.

Based on the description of some of the variables forming OCB which are related to employee performance which is the ultimate goal of this study, a problem formulation can be formulated: Does Leadership Style, Organizational Culture, Compensation affect performance either directly or through variables between Organizational Citizenship Behavior. The purpose of this study is to examine and analyze the influence of Leadership Style, Organizational Culture, Compensation on Performance, either directly or through variables between Organizational Citizenship Behavior.

This research was conducted in connection with wanting to determine the influence of several variables forming OCB behavior. This study still has limitations, 
namely the variables and the number of samples taken. It is suggested for the next research that this limitation should be considered in order to improve the research results.

\section{RESEARCH METHODS}

This type of research is a quantitative research. Quantitative research is research that requires a lot of use of numbers, starting from data collection, interpretation, and display of result files (Sugiyono, 2014).

In this study the variables studied were leadership Style (X1), Organizational Culture (X2), Compensation (X3), Organizational Citizenship Behavior (Z) and Lecturer Performance (Y). Leadership style is measured by indicators of acceptability aspects, capability aspects, integrity aspects. Organizational culture is measured by indicators of innovation and risk taking, attention to detail, results orientation, people orientation, team orientation, aggressiveness, stability. Compensation is measured by indicators of salary, incentives, transportation allowances, health benefits, and family allowances. Organizational Citizenship Behavior variables are measured by indicators of altruism. conscientiousness, sportmanship, courtessy, and civic virtue. Performance variables are measured by quantity, quality, and timeliness. The population in this study were lecturers at private universities in Jember. Samples taken were 100 (Ferdinand, 2005). The sampling method was carried out in 2 stages, the first was choosing private universities with purposive sampling and then selecting respondents based on simple random sampling. The data analysis method used wasstructural equation modeling (SEM) using AMOS software .

\section{RESULTS ANALYSIS}

\section{Respondent Characteristics}

Respondents in this study were as many as 100 lecturers in private universities in Jember Regency, selected using purposive sampling and simple random sampling technique. The number of respondents who were male were 61 and female were 39 . From the education level, most of the S2 were 90 and S3 were 10. Then when viewed from the academic positions the largest number was as many as 46 Assistant Profesor, 14 Associate Profesor and Instructor as many as 40 people. The greatest number of working periods at intervals of more than 6 years to 15 years is 65 , over 15 years to 35 years is 15 and 20 people are the same or less than 5 years. When viewed from the Lecturer Certification, 64 and 36 have not obtained lecturer certification, where some are in the submission process. The college taken is the University Moch Sroedji, Muhammadiyah University, Mandala College of Economics, and the Al-Falah As-Sunniyyah Islamic Institute.

Description of respondents' answers to research variables:

\section{Description of Leadership Style X1}

Table 1. Leadership Style Variables

\begin{tabular}{clccccccc}
\hline No. & Leadership Style & STS & TS & CS & S & SS & Total & Mode \\
\hline 1 & Statement X1.1 & 1 & 7 & 29 & 32 & 31 & 100 & S \\
2 & Statement X1.2 & 2 & 6 & 29 & 34 & 29 & 100 & S \\
3 & Statement X1.3 & 0 & 8 & 32 & 29 & 31 & 100 & CS \\
4 & Statement X1.4 & 0 & 8 & 32 & 28 & 32 & 100 & CS \\
5 & Statement X1.5 & 1 & 7 & 32 & 28 & 32 & 100 & CS \\
\hline
\end{tabular}

Data source: Primary data processed

Based on table 1, it can be seen that most of the respondents gave agreed responses and strongly agreed. The right leadership style will make employees feel 
happy and calm at work and will ultimately make work productivity or performance high. From the respondents' answers to the Leadership Style indicators, most of which answered agree and strongly agree, it can be concluded that an exemplary personality, the ability to create a culture and organizational climate that is conducive and innovative, competence, has the ability to work with other parties, the ability to work constructively, creatively and integrative are some of the characteristics a leader needs to have.

\section{Description of Organizational Culture Variables X2}

Table 2. Organizational Culture Variables X2

\begin{tabular}{ccccccccc}
\hline No. & $\begin{array}{c}\text { Organizational } \\
\text { culture }\end{array}$ & STS & TS & CS & S & SS & total & Mode \\
\hline 1 & Statement X2.1 & 1 & 7 & 35 & 26 & 31 & 100 & CS \\
2 & Statement X2.2 & 0 & 8 & 37 & 29 & 32 & 106 & CS \\
3 & Statement X2.3 & 1 & 9 & 29 & 31 & 30 & 100 & S \\
4 & Statement X2.4 & 1 & 6 & 29 & 33 & 31 & 100 & S \\
5 & Statement X2.5 & 1 & 9 & 31 & 26 & 33 & 100 & CS \\
6 & Statement X2.6 & 0 & 8 & 29 & 28 & 37 & 102 & CS \\
7 & Statement X2.7 & 1 & 7 & 32 & 26 & 34 & 100 & S \\
\hline
\end{tabular}

Data source: Primary data processed

Based on table 2, it can be seen that most of the respondents agreed and strongly agreed. This shows that Organizational Culture is the most important thing to consider in an organization. Organizational culture is the way people do things in organizations. It is a unit of norms consisting of beliefs, attitudes, core values and behavior patterns carried out by people in the organization. Common beliefs, core values and behavior patterns affect individual performance and ultimately will affect organizational performance. In a good work culture, people will work with high enthusiasm so that the productivity of their work is good.

\section{Description of Compensation Variable X3}

Table 3. Compensation Variable X3

\begin{tabular}{clccccccc}
\hline No. & Compensation & STS & TS & CS & S & SS & total & Mode \\
\hline 1 & Statement X3.1 & 0 & 8 & 32 & 26 & 34 & 100 & $\mathrm{~S}$ \\
2 & Statement X3.2 & 0 & 8 & 32 & 27 & 33 & 100 & $\mathrm{~S}$ \\
3 & Statement X3.3 & 0 & 8 & 32 & 26 & 34 & 100 & $\mathrm{~S}$ \\
4 & Statement X3.4 & 0 & 8 & 32 & 28 & 32 & 100 & $\mathrm{CS}$ \\
5 & Statement X3.5 & 0 & 8 & 32 & 26 & 34 & 100 & $\mathrm{~S}$ \\
6 & Statement X3.6 & 0 & 8 & 32 & 26 & 34 & 100 & $\mathrm{~S}$ \\
\hline
\end{tabular}

Data source: processed primary data

Based on table 3, it can be seen that the answers of respondents to indicators of compensation, such as salaries, incentives, and various allowances, mostly agreed and strongly agreed. This shows that Compensation is the most important thing to pay attention to in an organization in order to improve performance, for example a company or in this research is in Higher
Education. By giving the right compensation will make employees work well.

\section{Variable Description Organization Citizenship Behavior Y2}

A recapitulation of respondents' answers to the Organizational Citizenship Behavior variable can be explained as follows: 
Table 4. Compensation Variable Z

\begin{tabular}{ccccccccc}
\hline No. & $\begin{array}{c}\text { Organizational } \\
\text { Citizenship } \\
\text { Behavior }\end{array}$ & STS & TS & CS & S & SS & total & Mode \\
\hline 1 & Statement Z1.1 & 1 & 8 & 30 & 32 & 29 & 100 & S \\
2 & Statement Z1.2 & 1 & 4 & 32 & 33 & 30 & 100 & S \\
3 & Statement Z1.3 & 0 & 3 & 32 & 34 & 31 & 100 & S \\
4 & Statement Z1.4 & 1 & 2 & 32 & 32 & 33 & 100 & SS \\
5 & Statement Z1.5 & 0 & 5 & 30 & 32 & 33 & 100 & SS \\
6 & Statement Z1.6 & 1 & 6 & 29 & 31 & 33 & 100 & SS \\
7 & Statement Z1.7 & 0 & 5 & 32 & 31 & 32 & 100 & CS \\
8 & Statement Z1.8 & 0 & 2 & 31 & 39 & 28 & 100 & S \\
9 & Statement Z1.9 & 1 & 6 & 32 & 29 & 31 & 99 & SS \\
\hline Data source: processed primary data & & & & & &
\end{tabular}

Based on table 4 , it can be seen that most of the respondents agreed and strongly agreed. This shows that Organizational Citizenship Behavior although this means doing work other than related to its main tasks and functions or doing work beyond what is expected by an organization will affect the performance of both individual performance and in the end will make the performance of an organization effective.

\section{Description of Lecturer Performance Variables Y1}

Table 5: Lecturer Performance Variables (Y1)

\begin{tabular}{ccccccccc}
\hline No. & Compensation & STS & TS & CS & S & SS & total & Mode \\
\hline 1 & Statement X3.1 & 1 & 8 & 29 & 32 & 30 & 100 & S \\
2 & Statement X3.2 & 0 & 7 & 30 & 32 & 31 & 100 & S \\
3 & Statement X3.3 & 1 & 8 & 27 & 33 & 31 & 100 & SS \\
4 & Statement X3.4 & 1 & 6 & 31 & 41 & 21 & 100 & S \\
5 & Statement X3.5 & 0 & 4 & 34 & 29 & 33 & 100 & S \\
\hline
\end{tabular}

Based on table 5, it can be seen that most of the respondents agreed and strongly agreed. This shows that PTS lecturers in Jember mostly try to complete their work according to standards both in quantity and quality, work carefully, are rarely absent and do work according to the specified time limit.

\section{Results of data analysis}

In this study, the data analysis method used is structural equation modeling (SEM) using AMOS software. The series of data processing includes testing measurement models, including validity and reliability, while structural model testing includes testing the significance of the influence of independent or exogenous variables on dependent or endogenous variables.

\section{Measurement Model Test}

Validity and reliability testing is carried out in order to test whether the indicator variables used are truly significant in terms of reflecting the construct or latent variables (convergent validity). Some of the measures to be tested are the Standardized Loading Factor (SLF) measures. Good convergent validity is indicated by a high standardized loading factor (SLF) value. (Hair 2010) suggested an SLF value of 0.5. Table 6. presents the SLF value of each of the $\mathrm{X} 1, \mathrm{X} 2, \mathrm{X} 3, \mathrm{Z}$ and $\mathrm{Y}$ variables $\geq$ 
Table 6. SLF Value Based on Variables $\mathrm{X} 1, \mathrm{X} 2, \mathrm{X} 3, \mathrm{Z}$ and $\mathrm{Y}$

\begin{tabular}{cc}
\hline Indicator & Standardized Loading Factor \\
\hline X11 & 0.941 \\
X12 & 0.937 \\
X13 & 0.937 \\
X14 & 0.940 \\
X15 & 0.944 \\
X21 & 0.952 \\
X22 & 0.952 \\
X23 & 0.952 \\
X24 & 0.952 \\
X25 & 0.952 \\
X26 & 0.952 \\
X27 & 0.952 \\
X31 & 0.952 \\
X32 & 0.946 \\
X33 & 0.952 \\
X34 & 0.939 \\
X35 & 0.952 \\
X36 & 0.952 \\
Z11 & 0.946 \\
\hline
\end{tabular}

\begin{tabular}{cc}
\hline Indicator & Standardized Loading Factor \\
\hline Z12 & 0.939 \\
Z13 & 0.946 \\
Z14 & 0.939 \\
Z15 & 0.939 \\
Z16 & 0.939 \\
Z17 & 0.932 \\
Z18 & 0.946 \\
Z19 & 0.946 \\
Y11 & 0.930 \\
Y12 & 0.937 \\
Y13 & 0.944 \\
Y14 & 0.944 \\
Y15 & 0.944 \\
\hline
\end{tabular}

Source; Primary data is processed in 2020

Based on Table 6, it can be seen that all the standardized loading factor (SLF) values of each indicator are> 0.5. This shows that good convergent validity has been achieved based on the SLF measure. In accordance with Figure 1. which is assisted by the Amos Data Analysis tool.

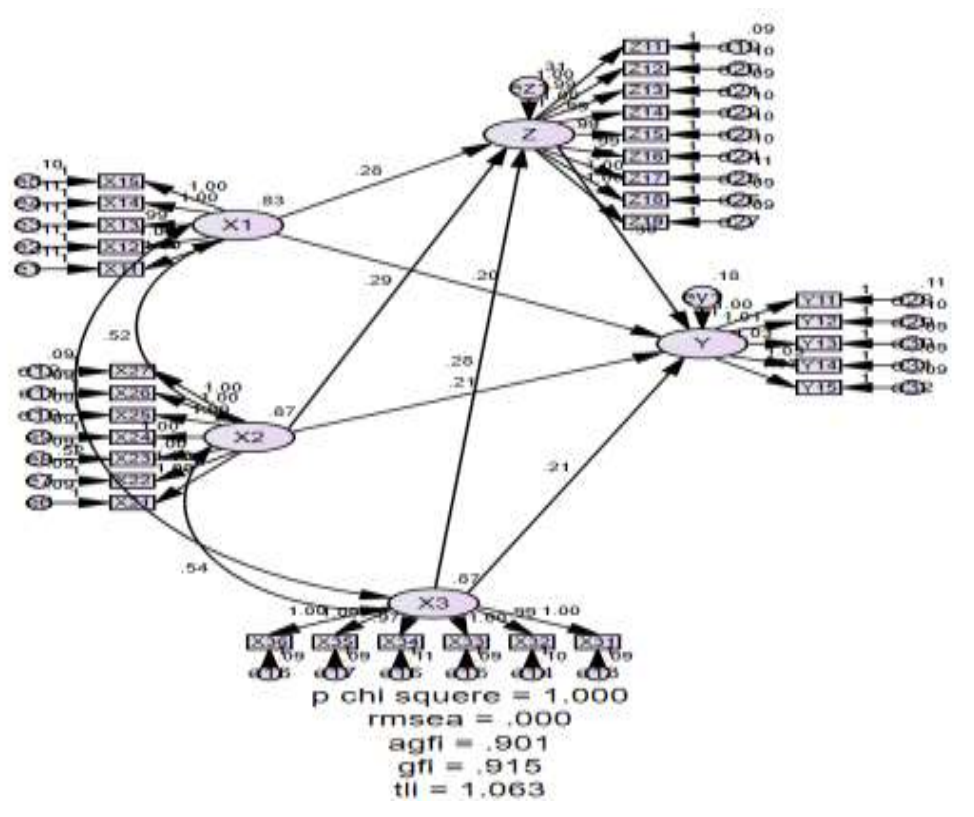

Figure 1. Result Analysis

The next test is to calculate reliability. The level of reliability is measured by the composite reliability value. On composite reliability the minimum value set to indicate that the construct is acceptable is 0.7. If the composite reliability is greater than 0.7 , the construct passes the reliability test. The results of the construct reliability test can be seen in Table 7 . 
Table 7. Test Results of composite reliability

\begin{tabular}{ccc}
\hline Variable & $\begin{array}{c}\text { Composite } \\
\text { Reliability }\end{array}$ & Information \\
\hline $\begin{array}{c}\text { Leadership } \\
\text { Style }\end{array}$ & 0.921 & Reliability \\
$\begin{array}{c}\text { Organizational } \\
\text { culture }\end{array}$ & 0.897 & Reliability \\
Compensation & 0.835 & $\begin{array}{l}\text { Reliability } \\
\text { Reliability }\end{array}$ \\
$\begin{array}{c}\text { Organizational } \\
\text { Citizenship }\end{array}$ & 0.856 & \\
Behavior & & \\
Performance & 0.881 & Reliability \\
\hline Source; Primary data is processed in 2020
\end{tabular}

Source; Primary data is processed in 2020

From the table Composite ReliabilityTable 7 shows that the Composite Reliability value for each construct is greater than 0.7. This indicates that the constructs that have been tested are reliable.

Model fit test

Table 8 presents several measures for testing the SEM model as a whole:
Table 8. Overall Model Fit Test

\begin{tabular}{|c|c|c|c|}
\hline Measures & Score & $\begin{array}{l}\text { Benchmark } \\
\text { Value }\end{array}$ & $\begin{array}{l}\text { Model } \\
\text { Fit to } \\
\text { Data }\end{array}$ \\
\hline RMSEA & 0.000 & $<0.1$ & Yes \\
\hline $\begin{array}{l}\text { P chi- } \\
\text { square }\end{array}$ & 1,000 & $>0.05$ & Yes \\
\hline AGFI & 0.901 & $>0.9$ & Yes \\
\hline GFI & 0.915 & $>0.9$ & Yes \\
\hline TLI & 1,063 & $>0.9$ & Yes \\
\hline
\end{tabular}

Source; Primary data is processed in 2020

Based on Table 8, the results show that the SEM model as a whole has a good ability in terms of matching the sample data (good fit). This means that the 5 criteria studied have met the suitability of the model

\section{Structural Model Test Significance Test}

Furthermore, structural model testing will be carried out, namely testing the significance of the effect. Table 9 test results of the significance of the direct effect.

Table 9. Testing the Significance of Direct Influence

\begin{tabular}{cccc}
\hline Direct Influence & Path Coefficient & Significance Test & R-Square \\
\hline $\mathrm{X} 1->\mathrm{Z}$ & 0.278 & $\mathrm{p}=0.002<0.05$ (Significant) & 0.6 \\
$\mathrm{X} 2->\mathrm{Z}$ & 0.287 & $\mathrm{p}<0.001$ (Significant) & \\
$\mathrm{X} 3->\mathrm{Z}$ & 0.283 & $\mathrm{p}=0.001<0.05$ (Significant) & \\
\hline $\mathrm{X} 1->\mathrm{Y}$ & 0.203 & $\mathrm{p}=0.006<0.05$ (Significant) & 0.745 \\
$\mathrm{X} 2->\mathrm{Y}$ & 0.205 & $\mathrm{p}=0.004<0.05$ (Significant) & \\
$\mathrm{X} 3$ - $>\mathrm{Y}$ & 0.211 & $\mathrm{p}=0.004<0.05$ (Significant) & \\
$\mathrm{Z}->\mathrm{Y}$ & 0.304 & $\mathrm{p}<0.001$ (Significant) & \\
\hline
\end{tabular}

Source; Primary data is processed in 2020

Based on the results in Table 9:

$\Rightarrow$ It is known that X1 (Leadership Style) has a positive effect on $\mathrm{Z}$ (OCB), with a path coefficient value of 0.278 , and significant, with $\mathrm{p}=$ $0.002<0.05$.

$\Rightarrow$ It is known that X2 (Organizational Culture) has a positive effect on $\mathrm{Z}$ (OCB), with a path coefficient of 0.287 , and is significant, with $\mathrm{p}$ $<0.001$ which means $<0.05$.

$\Rightarrow$ It is known that $\mathrm{X} 3$ (compensation) has a positive effect on $\mathrm{Z}$ (OCB), with a path coefficient value of 0.283 , and significant, with $\mathrm{p}=$ $0.001<0.05$.

$\Rightarrow$ It is known that the R-Square value is 0.6, which means X1 (Leadership Style), X2 (Organizational Culture), and $\mathrm{X} 3$ (Compensation) are able to influence $\mathrm{Z}(\mathrm{OCB})$ by $60 \%$.

$\Rightarrow$ It is known that $\mathrm{X} 1$ (Leadership Style) has a positive effect on $\mathrm{Y}$ (Lecturer Performance), with a path coefficient value of 0.203 , and significant, with $\mathrm{p}=0.006<0.05$. 
$\Rightarrow$ It is known that $\mathrm{X} 2$ (Organizational Culture) has a positive effect on $\mathrm{Y}$ (Lecturer Performance), with a path coefficient value of 0.205 , and significant, with $\mathrm{p}=0.004<0.05$.

$\Rightarrow$ It is known that X3 (Compensation) has a positive effect on Y (Lecturer Performance), with a path coefficient of 0.211, and is significant, with $\mathrm{p}=0.004<0.05$.

$\Rightarrow$ It is known that $\mathrm{Z}$ (OCB) has a positive effect on $\mathrm{Y}$ (Lecturer Performance), with a path coefficient value of 0.304 , and significant, with $\mathrm{p}<0.001$ which means $<0.05$.

$\Rightarrow$ It is known that the R-Square value is 0.745 , which means $\mathrm{X} 1$ (Leadership $\quad$ Style), $\quad$ X2 (Organizational Culture), $\mathrm{X} 3$ (Compensation), and $\mathrm{Z}(\mathrm{OCB})$ are able to influence $\mathrm{Y}$ (Lecturer Performance) by $74.5 \%$.

Table 10. presents the results of the mediation test using the Sobel test.

Table 10. Mediation Test with Sobel Test

\begin{tabular}{ccccc}
\hline Direct Influence & Path Coefficient & Std. Error & Indirect Influence & Z Sobel \\
\hline X1 -> Z & 0.278 & 0.089 & X1 $>$ Z $>$ Y $=0.278 * 0.304=0.0845$ & 2,364 \\
X $->$ Z & 0.287 & 0.087 & X2 $>$ Z $>$ Y $=0.287 * 0.304=0.0872$ & 2,437 \\
X3 -> Z & 0.283 & 0.087 & X3 $>$ Z $>$ Y $=0.283 * 0.304=0.0860$ & 2,419 \\
Z -> Y & 0.304 & 0.084 & & \\
\hline
\end{tabular}

Source; Primary data is processed in 2020

Based on the results of the Sobel test in Table 10 .:

$\Rightarrow$ The indirect effect of X1 (Leadership Style) on Y (Lecturer Performance), through $\mathrm{Z}$ (OCB) is 0.0845 . It is known that $\mathrm{Z}$ is significant as a mediator of the relationship between X1 (Leadership Style) and Y (Lecturer Performance), with the $\mathrm{Z}$ value (OCB) Sobel $=2.364>1.96$.

$\Rightarrow$ The indirect effect of X2 (Organizational Culture) on $\mathrm{Y}$ (Lecturer Performance), through $\mathrm{Z}$ (OCB) is 0.0872 . It is known that $\mathrm{Z}$ is significant as a mediator of the relationship between $\mathrm{X} 2$ (Organizational Culture) and $\mathrm{Y}$ (Lecturer Performance), with the $\mathrm{Z}$ (OCB) Sobel value $=2.437>1.96$.

The indirect effect of $\mathrm{X} 3$ (Compensation) on $\mathrm{Y}$ (Lecturer Performance), through $\mathrm{Z}$ (OCB) is 0.0860 . It is known that $\mathrm{Z}$ is significant as a mediator of the relationship between X3 (Compensation) and $\mathrm{Y}$ (Lecturer Performance), with the $\mathrm{Z}$ value (OCB) Sobel $=2.419>1.96$.

\section{INTERPRETATION}

The interpretation of the results of this study is divided into four groups, namely the direct influence of variable $\mathrm{X}$ (Leadership Style, Organizational Culture, and Compensation) on Z (Organizational Citizenship Behavior), direct influence of variable $\mathrm{X}$ (Leadership Style, Organizational Culture, and Compensation) on Y (Performance Lecturer), pengaruh direct variable $\mathrm{Z}$ (Organizational Citizenship Behavior) on the variable $Y$ (Lecturer Performance), and the indirect effect of X (Leadership Style, Organizational Culture, and Compensation) against Y(Lecturer Performance) through $\mathrm{Z}$ (Organizational Citizenship Behavior).

\section{The Influence of Leadership Style on Organizational Citizenship Behavior}

The first path test is about the influence of the Leadership Style variable (X1) on the variables Organizational Citizenship Behavior(Z), the path coefficient value is 0.278 with a significance value of 0.002 . 
The significance value of 0.002 is smaller than $\alpha(p<0.05)$, indicating that Leadership Style (X1) has a significant effect on Organizational Citizenship Behavior( $(Z)$. Then $\mathrm{H} 1$ is supported. The conclusion that can be drawn is that if existing leaders can be accepted who have exemplary personalities, have the competence and ability to carry out their duties, have the ability to work constructively, creatively and integratively, it will make the lecturers happy and willing to work well even beyond. what should be implemented is the Tri Dharma activity which is the task of a lecturer. Working beyond what is expected or outside of this main task and function is what is called Organizational Citizenship Behavior.This result is reinforced by the distribution of respondents' answers about the indicators of Leadership Style, most of the respondents answered agree and strongly agree. This research supports the research conducted by Pratikto et al (2016), Malik et al (2016) where Leadership Style affects Organizational Citizenship Behavior and is in line with previous research from (Iis Kartini, 2017) which states that Leadership Style has a positive and significant effect on Organizational Citizenship Behavior.

\section{The Influence of Organizational Culture on Organizational Citizenship Behavior}

The second path examination is about the influence of the Organizational Culture (X2) variable on the variables Organizational Citizenship Behavior(Z), the path coefficient value is 0.287 with a significance value of 0.001 . The significance value of 0.001 is smaller than $\alpha(\mathrm{p}<0.05)$, indicating that Organizational Culture (X2) has a significant effect on Organizational Citizenship Behavior(Z). Then $\mathrm{H} 2$ is supported. This shows that the better the Organizational Culture that supports each other's colleagues which includes encouraging more creativity, focusing on benefits rather than just processes, working in teams is preferred, and emphasizing growth, the
Organizational Culture has a positive influence on the Organization Citizenship Behavior in lecturer. This result is reinforced by the distribution of respondents' answers about the indicators of organizational culture, most of the respondents answered agree and strongly agree. This research supports research conducted by (Ahmadi,2010) where Organizational Culture influences Organizational Citizenship Behavior and is in line with previous research from (Dea Satya Putra et al. 2018) which states that Organizational Culture has a positive and significant effect on Organizational Citizenship Behavior.

\section{The Effect of Compensation on Organizational Citizenship Behavior}

Testing the third path about the influence of the compensation variable (X3) on the variable Organizational Citizenship Behavior(Z), the path coefficient value is 0.283 with a significance value of 0.001 . The significance value of 0.001 is smaller than $\alpha(\mathrm{p}<0.05)$, indicating that compensation has a significant effect on the variableOrganizational Citizenship Behavior. Then H3 is supported. This shows that the better the compensation which includes the salary that is given according to expectations, the institution pays attention to the needs / facilities of lecturers, and provides various benefits such as health allowances, transportation allowances, family allowances and rewards for outstanding lecturers, it will have a positive influence on Organization Citizenship. Behavior in Lecturers. This research supports research conducted by (Muayanah et al. 2015) where Compensation affects Organizational Citizenship Behavior and is in line with previous research from (Prasetya and Ahyar Yuniawan ,2016), AA Ngurah Bagus Naendra and $\mathrm{Ni}$ Wayan Mujiati ,2016) which states that compensation has a positive and positive effect. significant to Organizational Citizenship Behavior. 
Organizational Citizenship Behavior, such as: attitude and willingness to help colleagues (altruism), doing work beyond what is expected by the institution (conscientiousness), tolerating less than ideal conditions (sportmanship), maintaining good relations with colleagues and avoiding from interpersonal problems (Courtessy), feeling responsible for the institution (Civic virtue).

\section{The Effect of Leadership Style on Lecturer Performance}

Testing the fourth path about the influence of the leadership style variable (X1) on the variable Lecturer Performance $(\mathrm{Y})$, the path coefficient value is 0.203 with a significance value of 0.006 . The significance value of 0.006 is smaller than $\alpha(\mathrm{p}<0.05)$, indicating that Leadership Style (X1) has a significant effect onLecturer Performance(Y). Then $\mathrm{H} 4$ is supported. This shows that the more appropriate the applied leadership style which includes existing leaders can be accepted who have exemplary personalities, have the competence and ability to carry out their duties, have the ability to work constructively, creatively and integratively will make lecturers' performance in this case include activities. tri dharma which is the main task and function of a lecturer becomes good. In this study, good performance is proven not only limited to Tri Dharma but also implementing Organizational Citizenship Behavior. This result is reinforced by the distribution of respondents' answers about indicators of Leadership Style, most of the respondents answered agree and strongly agree. This research supports research conducted by (Heylen Amildha Yanuarita, 2018) in which Leadership Style has an effect on lecturer performance.

\section{The Influence of Organizational Culture on Lecturer Performance}

Testing the fifth path about the influence of the Organizational Culture variable (X2) on variables Lecturer
Performance(Y), the path coefficient value is 0.205 with a significance value of 0.004 . The significance value of 0.004 is smaller than $\alpha \quad(p<0.05)$, indicating that Organizational Culture (X2) has a significant effect onLecturer Performance (Y). Then H5 is supported. This shows that the better the Organizational Culture that supports each other's colleagues which includes encouraging more creativity, focusing on benefits rather than just processes, working in teams is preferred, and emphasizing growth, the Organizational Culture has a positive influence onLecturer Performance(Y). This result is reinforced by the distribution of respondents' answers about indicators of Organizational Culture, most of the respondents answered agree and strongly agree. This research supports research conducted by (Tatik Fidowaty and Poni Sukaesi Kurniati ,2015) in which Organizational Culture has an effect on Lecturer Performance.

\section{The Effect of Compensation on Lecturer Performance}

The sixth path test is about the influence of the compensation variable (X3) on the variable Lecturer Performance(Y), the path coefficient value is 0.211 with a significance value of 0.004 . The significance value of 0.004 is smaller than $\alpha$ ( $\mathrm{p}<0.05)$, indicating that compensation has a significant effect on the variableLecturer Performance(Y). Then H6 is supported. This shows that the better the compensation which includes the salary given according to expectations, the salary according to the sweat expended, the institute pays attention to the needs / facilities of the lecturers, and provides various allowances such as health allowances, transportation allowances, family allowances and rewards for outstanding lecturers, then will have a positive influence on Lecturer Performance (Y). This result is reinforced by the distribution of respondents' answers about indicators of Organizational Culture, most 
of the respondents answered agree and strongly agree. This study supports research conducted by (Muhammad Arifin, 2017) where compensation has a significant and positive effect on lecturer performance

\section{The Effect of Organizational Citizenship Behavior on Lecturer Performance}

Seventh path testing about the influence of variables Organizational Citizenship Behavior ( $\mathrm{Z}$ ) to the variable Lecturer Performance(Y), the path coefficient value is 0.304 with a significance value of 0.001 . The significance value of 0.001 is smaller than $\alpha(p<0.05)$, indicating thatOrganizational Citizenship Behavior significant effect on variables Lecturer Performance $(Y)$. Then $\mathrm{H} 7$ is supported. This shows that it is getting betterOrganizational Citizenship Behavior which includes, for example: the attitude and behavior of willingness to help colleagues (altruism), doing work beyond what the institution expects (conscientiousness), tolerating less than ideal conditions (sportmanship), maintaining good relations with colleagues and avoiding interpersonal problems (Courtessy), feel responsible for the institution (Civic virtue) has a positive influence on Lecturer Performance (Y). This result is reinforced by the distribution of respondents' answers about the indicators of Organizational Citizenship Behavior, most of which answered agree and strongly agree. This research is in line with research conducted by (Maghfirah and Wahyu Maulid Adha ,2017) which concluded that the Organization Citizenship Behavior has an effect on Lecturer Performance.

\section{For Indirect Influence}

The Effect of Leadership Style on Lecturer Performance Through Organizational Citizenship Behavior Variables as Intervening Variables

Testing the eighth path about the influence of the variable Leadership Style (X1) on variables Lecturer Performance
(Y) through variables Organizational Citizenship Behavior ( $\mathrm{Z}$ ) as an intervening variable, it is known that the $Z$ value of significance as a mediator of the relationship is 2.364 in other words, it means that the value of the effect of mediation is greater at the 0.05 significance level, namely 1.96 (2.364> 1.96), it can be concluded that there is mediating influence Organizational Citizenship Behavior $(Z)$ in mediating the relationship between Leadership Style (X1) and lecturer performance (Y). Then $\mathrm{H} 8$ is supported. This shows that in the right leadership style will be able to encourage lecturers to carry out their performance not only limited to their main tasks in Tri Darma but able to encourage lecturers to carry out the work above that is expected by the institution in this case universities. This behavior is called Organizational Citizenship Behavior (OCB) which includes the attitude and behavior of willingness to help colleagues (altruism), doing work beyond what the institution expects (conscientiousness), tolerating less than ideal conditions (sportmanship), maintaining good relations with colleagues and avoiding interpersonal problems. (Courtessy), felt responsible for the institution (Civic virtue). The OCB behavior that is carried out will have an impact on the overall institutional performance. If the lecturer carries out OCB, the assumption is that the main tasks and functions in Tri Dharma have also been carried out, so it can be concluded that the right leadership style will encourage the emergence of OCB behavior and will ultimately affect the performance of lecturers in the end it will make the overall performance of the higher education good as well. This result is reinforced by the distribution of respondents' answers about indicators of Organizational Culture, most of the respondents answered agree and strongly agree. This research is in line with the research conducted by (Maghfirah and Wahyu Maulid Adha, 2017) where the Organizational Citizenship Behavior influencesmediation betweenrelationship of 
Leadership Style (X1) to lecturer performance (Y).

\section{The Influence of Organizational Culture on Lecturer Performance through Organizational Citizenship Behavior Variables as Intervening Variables}

The ninth path examination is about the influence of the Organizational Culture (X2) variable on the variables Lecturer Performance (Y) through variables Organizational Citizenship Behavior (Z) as an intervening variable, it is known that the $\mathrm{Z}$ value of significance as a mediator of the relationship is 2.437 in other words, it means that the value of the effect of mediation is greater at the 0.05 significance level, namely 1.96 (2.437> 1.96), it can be concluded that there is mediating influence Organizational Citizenship Behavior (Z) in mediating the relationship between Organizational Culture (X2) and lecturer performance (Y). Then H8 is supported. This shows that a good organizational culture will encourage behavior Organizational Citizenship Behavior lecturers and furthermore will make the lecturers' performance be good.

Organizational Citizenship Behavior give mediation effect between the relationship between Organizational Culture (X2) and lecturer performance (Y). This result is reinforced by the distribution of respondents' answers about indicators of Organizational Culture, most of the respondents answered agree and strongly agree. This research is in line with the research conducted by (Maghfirah and Wahyu Maulid Adha, 2017) where Organizational Citizenship Behavior give mediation effect between the relationship between Organizational Culture (X2) and lecturer performance $(\mathrm{Y})$.

\section{The Effect of Compensation on Lecturer Performance through Organizational Citizenship Behavior as an Intervening Variable}

The tenth path test is about the influence of the compensation variable (X3) on the variable Lecturer Performance (Y) through variables Organizational Citizenship Behavior $(Z)$ as an intervening variable, it is known that the $\mathrm{Z}$ value of significance as a mediator of the relationship is 2.419 in other words, it means that the value of the effect of mediation is greater at the 0.05 significance level, namely 1.96 (2.419> 1.96), it can be concluded that there is Organizational Citizenship Behavior (Z) has a role in mediating the compensation relationship (X3) on lecturer performance $(\mathrm{Y})$. If the lecturer is satisfied with the compensation provided by the institution, the lecturer will voluntarily carry out the behavior Organizational Citizenship Behavior. Then H10 is supported. This shows that it is getting better Organizational Citizenship Behavior as seen from attitude and behavior of willingness to help colleagues (altruism), doing work beyond what is expected by the institution (conscientiousness), tolerating less than ideal conditions (sportmanship), maintaining good relations with colleagues and avoiding interpersonal problems (Courtessy), feeling responsible for the institution (Civic virtue)then the Organizational Citizenship Behavior (Z) gives a mediating effect between Compensation relationship (X3) to lecturer performance $(\mathrm{Y})$. This result is reinforced by the distribution of respondents' answers about the indicators of compensation, most of the respondents answered agree and strongly agree. This research is in line with research conducted by (Maghfirah and Wahyu Maulid Adha, 2017) where Organizational Citizenship Behavior give mediation effect between Compensation relationship (X3) to lecturer performance (Y).

\section{CONCLUSION}

Based on the results of the analysis, several points of conclusion can be drawn from this study, namely as follows:

a. The applied leadership style will influence and encourage the emergence 
of the Organizational Citizenship Behavior for PTS lecturers in Jember

b. The right organizational culture will influence and encourage emergence Organizational Citizenship Behavior for PTS lecturers in Jember

c. The compensation received will influence and encourage the emergence of the Organizational Citizenship Behavior for PTS lecturers in Jember

d. The applied leadership style will affect the performance of private universities in Jember

e. The right organizational culture will affect the performance of private universities in Jember

f. The compensation received will affect the performance of PTS lecturers in Jember

g. Leadership Style, Organizational Culture and Compensation affect the performance of lecturers through the Organization Citizenship Behavior of PTS lecturers in Jember

From the conclusions that have been written, it can be said that the improvement of lecturer performance can be done through building or shaping the Organizational Citizenship Behavior of PTS lecturers in Jember.

\section{IMPLICATION}

The implications or follow-up that can be drawn from the above conclusions are as follows:

Efforts are always made to build Organizational Citizenship Behavior because it is proven to be an intervening variable to improve the performance of private universities in Jember. Build behavior Organizational Citizenship Behavior PTS lecturers in Jember are carried out by applying leadership style variables that are able to encourage creativity, innovation, and a sense of responsibility towards their work as lecturers. If this is achieved, the effectiveness of PTS will be achieved and an increase in the competitiveness of PTS can be realized. Likewise with
Organizational Culture, Organizational Culture should always be pursued that encourages a good work culture, for example by creating values, shared beliefs that serve as guides and guidelines in working to create discipline, a sense of belonging and shared responsibility to achieve individual performance and institutional performance. In connection with Compensation, there is always an evaluation of the rules, regulations and policies on the provision of compensation. Always strived to provide satisfaction with the compensation that lecturers can receive. If there is satisfaction,

\section{REFERENCES}

Ahmadi, Freyedon. 2010 Survey of Beetwen OCB's Relationship and Internal and External Factor Impact on OCB. European Journal of Social Science Vol 16. No. 3

Ambarwati, Yuni (2013) The Influence of Motivation and Compensation on Organizational Citizenship Behavior of Non-Educational Employees, Muhammadiyah University of Yogjakarta.

http://repository.umy.ac.id/handle/1 23456789/17537.

Arifin, Muhammad. 2017. The Effect of Compensation and Ape Satisfaction on Performance (Dtudi on the Teacher Training and Education Faculty, Muhammadiyah University of North Sumatra). FKIP, University of North Sumatra. North Sumatra. Edu Tech Journal Vol. 3 No. September 2, 2017

Arumi, Sekar Mira et al (2019) Effect of Organizational Culture On Organizational Citizenship Bahavior With Organizational Commitment as Mediator, International Journal of Research in Business and Social Science, 8 (4) 2019, p. 124- 132.

Danendra, AA Ngurah Bagus and $\mathrm{Ni}$ Wayan Mujiati 02016) The Influence of Motivation, 
Compensation and Organizational Commitment on Organizational Citizenship Behavior (OCB), EJournal of Management of Udayana University, Vol5, No.10, 2016: 6229-6259, ISSN: 2302-8912.

Ferdinand. 2005. Management Research Methods. 2.BP Edition of Diponegoro University Semarang

Fidowaty, Tatik and Poni Sukaesi Kurniati. 2015. The Influence of Organizational Culture on Lecturer Performance at the Indonesian Computer University (UNIKOM). Journal of Political Science and Communication Vol. V No. December 2, 2015

Greenberg, Jerald and Robert Baron (2003). Behavior in Organizations (understanding and managing the human side of work), eight editions, prentice hall

Hasibuan, Malayu SP2007. Human Resource Management Company, Bandung, PT. Earth Aksa.

Kartini, 2017, The Influence of Leadership Style on Organizational Citizenship Behavior (OCB) at LP3I Polytechnic Jakarta, North Jakarta Campus, Journal of Lentera Bisnis Vol. 6 No.1, May 2017 / ISSN 2252-9993.

Kwantes, CT, Karam, Charlote M. 2008. Culture's Influence on The Perception of OCB as In Role or Extra Role. International Journal of Intercultural Relations, Vol. 32, p 229-243

Maghfirah and Wahyu Maulid Adha. 2017. The Influence of Organizational Citizenship Behavior (OCB) on Lecturer Performance at University of West Sulawesi. University of West Sulawesi. West Sulawesi. Equilibrium Journal Vol 3. No 3, September 2017.

Malik Sania Zahra, Maheen Saleem, Ramsha Naem, Effect of Leadership Styles on Organizational Citizenship behavior Employees of
Telecom Sector in Pakistan, Faculty of Economic and Social Review, Volume 54, No 2 (Winter 2016), pp 385-406.

Muayanah et al, 2015, The Effect of Compensation, Work Environment, and Organizational Commitment on Organizational Citizenship Behavior with Job Satisfaction as an Intervening Variable. (Study on Employees of PT. Fajar Lestari Sejati Semarang), Journal of Management Study Program, Pandanaran University, Semarang.

Nabawi Denny, Zunaidah \& M Kosasih Zain, The Influence Compensation and Motivation Employee Performance in PT Arwana Anugerah Keramik Tbk, JEMBATAN (Journal of Business Management and Teraoan) Year XV No, 1. April 2018.

Organ, DW Podsakof MP., Mackenzie, BS.2006, Organizational Citizenship Behavior, USA: Sage Publications, Inc

Putra et al, 2018, The Influence of Organizational Culture on Organizational Citizenship Behavior (OCB) with Job Satisfaction as an Intervening Variable (a study on Employees of Kusuma Agrowisata at the Hotel Division of Kota Batu). Journal of Business Administration (JAB) Vol. 62 No.2 September 2018, Faculty of Administrative Sciences, Brawijaya University, Malang.

Prasetyo Sindhi Saraayu and Ahyar Yuniawan (2016) Analysis of the Effect of Financial Compensation on Organizational Citizenship Behavior (OCB) with Work Discipline and Achievement Motivation as Mediation Variables, Diponegoro Journal of Management, Vol 5, Number 4, Year 2016, Pages 1-10.

Pratikto Bagus Tri, I ketut R Sudiartha, Sholikhah, The Influence of Job 
Satisfaction and Leadership Style on Organizational Citizhenship Behavior (Study at PT Ide Jaya Kreasindo), Indonesian Science Management Research Journal (JRMSI), Vol 6, No.2.2015 Hl 498515

Richard L. Daft. (2003). Management 8thed. Southwestern: Thomson

Sugiyono, PD (2014), Population and Sample of Qualitative, Quantitative and $\mathrm{R}$ \& $\mathrm{D}$ Research Methods (April 1952) 80
Yanuarita, Heylen Amildha. 2016. The Influence of Leadership Style on Lecturer Performance at Kadiri University, Kediri City, East Java. Kadiri University. Kediri. Sailing and Port Applications Journal, Vol \&, No 1, September 2016

Zang, et al. 2010. Leadership and Organizational Citizenship Behavior: OCB- Specific Meaning as mediator, Springers Science + Business Media 